\title{
Carotenoid composition and in vitro pharmacological activity of rose hips*
}

\author{
Györgyi Horváth ${ }^{1 凶}$, Péter Molnár ${ }^{1}$, Erika Radó-Turcsi², József Deli², Masami Kawase ${ }^{3}$, Kazue \\ Satoh ${ }^{4}$, Toru Tanaka5, Satoru Tani ${ }^{5}$, Hiroshi Sakagami ${ }^{6}$, Nóra Gyémánt ${ }^{7}$ and József Molnár ${ }^{7}$ \\ 'Department of Pharmacognosy, University of Pécs, Medical School, Pécs, Hungary; 2Department of Biochemistry and Medical Chemistry, \\ University of Pécs, Pécs, Hungary; ${ }^{3 F a c u l t y ~ o f ~ P h a r m a c e u t i c a l ~ S c i e n c e s, ~ M a t s u y a m a ~ U n i v e r s i t y, ~ M a t s u y a m a, ~ E h i m e, ~ J a p a n ; ~}{ }^{45}$ chool of Medi- \\ cine, Showa University, Shinagawa, Tokyo, Japan; ${ }^{5}$ Faculty of Pharmaceutical Sciences, Josai University, Sakado, Saitama, Japan; ${ }^{6}$ Division of \\ Pharmacology, Department of Diagnostic and Therapeutic Sciences, Meikai University School of Dentistry, Sakado, Saitama, Japan; ${ }^{7 F a c u l t y ~ o f ~}$ \\ Medicine, Institute of Medical Microbiology, Albert Szent-Györgyi Medical Centrum, University of Szeged, Szeged, Hungary
}

\begin{abstract}
The aim of the present study was to compare carotenoid extracts of Rose hips (Rosa canina L.) with regard to their phytochemical profiles and their in vitro anti-Helicobacter pylori ( $H$. pylori), cytotoxic, multidrug resistance (MDR) reversal and radical scavenging activity. Carotenoid composition was investigated in the different fractionation of rose hips, using extraction methods. Six main carotenoids - epimers of neochrome, lutein, zeaxanthin, rubixanthin, lycopene, $\beta, \beta$-carotene - were identified from Rose hips by their chromatographic behavior and UV-visible spectra, which is in accordance with other studies on carotenoids in this plant material. The active principles in the carotenoid extract might differ, depending upon the extraction procedures.
\end{abstract}

Key words: Rosa canina L., carotenoids, cytotoxic activity, anti-H. pylori, MDR, radical intensity

Received: 14 October, 2011; accepted: 01 March, 2012; available on-line: 17 March, 2012

\section{INTRODUCTION}

Carotenoids play an important role in preventing oxidative damage which are caused by free radicals in agerelated diseases such as cancer and ageing (Britton et al., 2005; Motohashi et al., 2003; Krinsky \& Johnson, 2005). Most current research is focused on a proposed role of carotenoids as lipid antioxidants which can protect the cells or hosts from the oxidation and other destructive processes mediated by singlet oxygen and free radicals, though more specific effects on the immune system are now under investigation (Britton et al., 2005; Krinsky \& Johnson, 2005). In this study, we present qualitative and quantitative data on the carotenoid content of Rose hips. We investigated anti-Helicobacter pylori ( $H$. pylori), cytotoxic, multidrug resistance (MDR) reversal and radical scavenging activity by the carotenoid extracts of Rose hips.

\section{MATERIALS AND METHODS}

Chemicals and reagents. They were obtained from the indicated companies: RPMI 1640 medium and Dulbecco's modified Eagle medium (DMEM) (Gibco BRL, Grand Island, NY, USA); fetal bovine serum (FBS) (JRH Bioscience, Lenexa, KS, USA); 3-(4,5-dimethylthiazol2-yl)-2,5-diphenyltetrazolium bromide (MTT), metronidazole, ascorbic acid, Rose Bengal and 2,2,6,6-tetramethyl- 4-hydroxy-piperideine (4-OH TEMP) (Wako Pure Chem. Ind., Ltd., Osaka, Japan); 1,1-diphenyl-2-picrylhydrazyl (DPPH) (Sigma Chem. Co., St. Louis, MO, USA); dextran sulphate (DS, 8 kD), (Kowa Chem. Co., Tokyo, Japan); $\beta, \beta$-carotene and gallic acid (Tokyo Kasei Co., Tokyo, Japan); clarithromycin (Taisho Pharmaceutical Co., Tokyo, Japan). $\alpha$-Tocopherol was a gift from Eisai Ltd. (Tokyo, Japan). A strain of H. pylori (ATCC 43504) was purchased from American Type Culture Collection (Rockville, MD, USA).

Isolation of phytoxanthins from Rose hips (Rosa canina L.). Rose hips (1.2 kg fresh weight) have been collected in the surroundings of Pécs (Hungary). Isolation of PM2 and PM9-PM12 in crystalline state was carried out in our laboratory according to reference of Molnár et al. (2005a). PM2: Phytoxanthins of Rose hips, $680 \mathrm{mg}$ crystalline sample; PM9: Hypophasic carotenoids of the ethereal extract of Rose hips, $176 \mathrm{mg}$ crystalline sample; PM10: Epiphasic carotenoids of the ethereal extract of Rose hips, $350 \mathrm{mg}$ crystalline sample; PM11: Hypophasic carotenoids of the $\mathrm{MeOH}$ extract of Rose hips, $96 \mathrm{mg}$ crystalline sample; PM12: Epiphasic carotenoids of the $\mathrm{MeOH}$ extract of Rose hips, $180 \mathrm{mg}$ crystalline sample.

HPLC analysis of samples PM2, PM9-12. HPLC was performed on a Dionex 580P NDG pump (Dionex Softron Germering, Germany) connected to a Dionex PDA-100 detector running Dionex Chromeleon software. Column: $250 \mathrm{~mm} \times 4.6 \mathrm{~mm}$ i.d., $6 \mathrm{~mm}$, endcapped Chromsyl C18. Gradient elution was performed with mixture of mobile phases as follows: A, $12 \% \mathrm{H}_{2} \mathrm{O}$ in $\mathrm{MeOH}$; B, $\mathrm{MeOH}$ : ad $\mathrm{C}, 30 \% \mathrm{CH}_{2} \mathrm{Cl}_{2}$ in $\mathrm{MeOH}$. Gradient program: 0-2 $\mathrm{min}, 100 \% \mathrm{~A}$; $2-10 \mathrm{~min}$, to $80 \% \mathrm{~A} 20 \% \mathrm{~B}$; $10-18 \mathrm{~min}$, to $50 \% \mathrm{~A} 50 \% \mathrm{~B} ; 18-25 \mathrm{~min}$, to $100 \% \mathrm{~B}$; 25-27 $\mathrm{min}, 100 \% \mathrm{~B}, 27-34 \mathrm{~min}$, to $100 \% \mathrm{C}$; $34-41 \mathrm{~min}$, 10\% C (in linear steps); flow rate: $1.2 \mathrm{ml} / \mathrm{min}$. Peak identification was at $450 \mathrm{~nm}$ (Deli et al., 2000). Carotenoids were identified on the basis of their UV-Vis spectroscopic

e-mail: gyorgyi.horvath@aok.pte.hu

* Presented at the 16th International Symposium on Carotenoids, 17-22 July, 2011, Kraków, Poland

Abbreviations: 4-OH TEMP, 2,2,6,6-tetramethyl-4-hydroxy-piperideine; 4-OH TEMPO, 2,2,6,6-tetramethyl-4-hydroxy-1-piperidinyloxy; BHI, brain heart infusion; DMEM, Dulbecco's modified Eagle medium; DPPH, 1,1-diphenyl-2-picrylhydrazyl; FBS, fetal bovine serum; HGF, human gingival fibroblasts; HSC-2, human oral squamous cell carcinoma; HSG, human submandibular gland tumor; MDR, multidrug resistance; MIC, minimum inhibitory concentration; MTT, 3-(4,5-dimethylthiazol-2-yl)-2,5-diphenyltetrazolium bromide. 
properties in different solvents, chemical reactions $[(E / Z)-$ isomerization (thermal isomerization and iodine-catalized photoisomerization), 5,6-epoxide $\rightarrow$ 5,8-epoxide (furanoid oxide) rearrangement, $\mathrm{NaBH}_{4}$-reduction], by co-chromatography with authentic reference samples (purity: $>95 \%$; HPLC) and by HPLC retention times (Deli et al., 2000).

Measurement of anti-H. pylori activity. The microdilution broth method was used to determine the minimum inhibitory concentration (MIC). Brain Heart Infusion (BHI) broth containing 10\% fetal bovibe serum (FBS) and $0.1 \%$ glucose was used as the medium and was cultured in a jar conditioned with AnaeroPack (Campylo, Mitsubishi Gas Chemical Co., Inc.). H. pylori was inoculated in the medium and cultured at $37^{\circ} \mathrm{C}$ for 2 days. The collected bacterial colonies were diluted to about $10^{7}$ colony forming unit $(\mathrm{CFU}) / \mathrm{ml}$ with the medium. The fractions were dissolved in DMSO, and then diluted with the medium. To the solution of the fractions, a suspension of bacteria was added to make $10^{6} \mathrm{CFU} / 150 \mathrm{~mL} /$ well. The mixture was incubated at $37^{\circ} \mathrm{C}$ for 5 days. The MIC values of the fractions were determined by observation (Kawase et al., 2003).

Cell culture. Human oral squamous cell carcinoma (HSC-2) cells (provided from Prof. Nagumo, Showa University) and human submandibular gland tumor (HSG) cells (provided from Dr. Atsumi, Meikai University) were maintained as monolayer cultures at $37^{\circ} \mathrm{C}$ in Dulbecco's modified Eagle medium (DMEM) supplemented with $10 \%$ heat-activated FBS in a humidified $5 \% \mathrm{CO}_{2}$ atmosphere, and subcultured by trypsinization. Human gingival fibroblasts (HGF) were isolated from the periodontal tissue of healthy gingival biopsy of a 10 -year-old female, as described previously (Sakagami et al., 2000), according to the guideline of Meikai University Ethic Committee, after obtainig the informed consent from the patients. Cells between the fifth and seventh passages were used.

Measurement of cytotoxic activity. Near confluent HSC-2 and HSG cells were incubated for $24 \mathrm{~h}$ with the indicated concentrations of test samples in culture medium in 96-microwell plates (Becton Dickinson and Company, Franklin Lakes, NJ, USA), and the viable cell number was determined by MT'T method (Sakagami et al., 2000). The cells were washed with PBS, and incubated for $4 \mathrm{~h}$ with fresh culture medium containing $0.2 \mathrm{mg} /$ $\mathrm{mL}$ MTT. After removing the medium, cells were lysed with $100 \mathrm{~mL}$ DMSO and the absorbance at $540 \mathrm{~nm}$ of the cell lysate was measured with Labsystems Mutiskan ${ }^{R}$ with Star/DOT Matrix printer JL-10. The $\mathrm{A}_{540}$ values of control HSC-2, HSG and HGF cells were 1.519, 0.884, and 0.283 , respectively. We found that the linearity of the absorbance value was maintained between $0-2.0$. The absorbance value of 1.0 was correlated to approximately $4 \times 10^{4}$ cells $/ \mathrm{cm}^{2}$. The $50 \%$ cytotoxic concentration $\left(\mathrm{CC}_{50}\right)$ was determined from the dose-response curve.

Measurement of the MDR reversal activity. The MDR1/A expressing cells were selected by culturing the infected cells with $60 \mathrm{ng} / \mathrm{mL}$ colchicine to maintain the expression of the MDR phenotype (Kessel, 1989). The L5178 MDR cell and the L5178 Y parent cell were grown in McCoy's 5A medium supplemented with $10 \%$ heat-inactivated horse serum, L-glutamine and antibiotics. The cells were adjusted to a concentration of $2 \times 10^{6} / \mathrm{ml}$ and resuspended in serum-free McCoy's $5 \mathrm{~A}$ medium, and $0.5 \mathrm{ml}$ aliquot of the cell suspension were distributed into each Eppendorf centrifuge tube. Then $10 \mu \mathrm{l}$ of $2 \mathrm{mg} / \mathrm{ml}$ test compounds (dissolved in DMSO) were added and incubated for $10 \mathrm{~min}$ at room temperature. Then $10 \mu \mathrm{l}$ rhodamine 123 as indicator of drug accumulation was added to the extracts $(5.2$ $\mu \mathrm{M}$ final concentration) and the cells were incubated for a further $20 \mathrm{~min}$ at $37^{\circ} \mathrm{C}$, washed twice and resuspended in
$0.5 \mathrm{ml}$ PBS ( $\mathrm{pH}$ 7.4) for analysis. The fluorescence intensity of cell population was measured by flow cytometry (instrument: Beckton Dickinson FACScan). ( \pm )-Verapamil was used as the positive control in R123 accumulation experiments (Weaver et al., 1993). The R123 accumulation was calculated from fluorescence of one height values. Then, the percentage of mean fluorescence intensity was calculated in treated MDR1 and parental cells, compared to untreated cells. The fluorescence activity ratio was calculated by following equation (Weaver et al., 1993):

MDR1 reversal activity $=($ MDR1 treated $/ M D R 1$ control $) /(\mathrm{pa}-$ rental treated/parental control)

\section{Measurement of the radical scavenging activity}

DPPH scavenging assay. For the determination of $\mathrm{DPPH}$ radical, $30 \mu \mathrm{L}$ of $300 \mu \mathrm{M} \mathrm{DPPH}$ in EtOH were added to $60 \mu \mathrm{L}$ of sample in $40 \%$ DMSO solution and analyzed $1 \mathrm{~min}$ after mixing. The microwave power, gain and time constant were changed to 5,400 and $0.1 \mathrm{~s}$, respectively (Molnár et al., 2005b).

${ }^{1} \mathbf{O}_{2}$ scavenging assay. The sample was added to the reaction mixture of $20 \mathrm{mM} 4-\mathrm{OH}$ TEMP and $20 \mu \mathrm{M}$ Rose Bengal in 20\% DMSO solution and the mixture in flat cell was irradiated for $5 \mathrm{~min}$ at $550 \mathrm{~nm}$ and analyzed by using ESR spectrometer. The microwave power, modulation width, the gain and time constant were changed to $5,0.2,200$ and 0.1 s. Singlet oxygen was measured by oxidation of 4-OH TEMP to 2,2,6,6-tetramethyl-4-hydroxy-1-piperidinyloxy (4-OH TEMPO) radical (Molnár et al., 2005b).

\section{RESULTS AND DISCUSSION}

\section{Carotenoid composition of PM2, and PM9-12 fractions}

On the basis of UV-VIS spectrum of the peaks, as well as the retention time and co-cromatography with authentic reference samples, the following carotenoids were identified in PM2 fraction (Molnár et al., 2001): antheraxanthin: $5.9 \%$; epimers of mutatoxanthin: $5.1 \%$; lutein + zeaxanthin: $59.7 \%$; (Z)-isomers of lutein and zeaxanthin: $1.5 \%$; rubixanthin $+\beta$-cryptoxanthin: $11.7 \%$; lycopene + (Z)-lycopene: $7.4 \% ; \beta, \beta$-carotene: $1.5 \%$. In the fraction of PM9 the following carotenoids were identified: (allE)-neoxanthin (1.3\%); (9'Z)-neoxanthin (2.1\%); epimers of neochrome $(8.8 \%)$; epimers of auroxanthin $(6.3 \%)$; lutein + zeaxanthin $(74.7 \%)$; (Z)-isomers of lutein and zeaxanthin $(2.1 \%)$; rubixanthin $+\beta$-cryptoxanthin $(0.9 \%)$. The main carotenoids of PM10 fraction were lycopene $(62.3 \%)$ and $\beta, \beta$-carotene $(23.9 \%)$. The fraction of PM11 contained epimers of neochrome (6.1\%); epimers

Table 1. Anti-H. pylori activity of Rose hips carotenoids

\begin{tabular}{lc}
\hline Extract & H. pylory $\left(\mathrm{MlC}_{50}, \mu \mathrm{g} / \mathrm{ml}\right)$ \\
\hline PM2 & 90 \\
PM9 & 21 \\
PM10 & 8.2 \\
PM11 & 11 \\
PM12 & 40 \\
Metronidazole & 7.0 \\
Amoxicilin & 0.023 \\
\hline
\end{tabular}


Table 2. Cyctotoxic activity of Rose hips carotenoids against tumor and normal cells

\begin{tabular}{|c|c|c|c|c|c|c|c|c|c|c|}
\hline \multirow{3}{*}{ Compound } & \multicolumn{9}{|c|}{$50 \%$ cytotoxic concentration $\left(\mathrm{CC}_{50}, \mu \mathrm{g} / \mathrm{ml}\right)$} & \multirow{3}{*}{$\begin{array}{l}\mathrm{Sla}=\mathrm{CC}_{50} \text { (normal) } \\
\mathrm{CC}_{50} \text { (tumor) }\end{array}$} \\
\hline & \multicolumn{5}{|c|}{ Human tumor cell } & \multicolumn{4}{|c|}{ Normal cell } & \\
\hline & HSC-2 & HSC-3 & HSC-4 & HepG2 & T98G & HL-60 & HGF & $\mathrm{HPC}$ & HPLF & \\
\hline PM2 & 73 & 81 & 50 & 84 & $>100$ & 15 & 89 & 69 & 96 & $<1.3$ \\
\hline PM9 & $>200$ & 98 & 77 & 188 & $>200$ & 15 & 195 & 154 & 191 & $>1.4$ \\
\hline PM10 & 44 & 79 & 36 & 71 & 160 & 14 & 144 & 85 & 152 & 1.9 \\
\hline PM11 & 12 & 38 & 23 & 14 & 68 & 3 & 78 & 25 & 98 & 2.5 \\
\hline PM12 & 154 & 161 & 104 & 145 & $>200$ & 39 & $>200$ & 85 & $>200$ & $><1.2$ \\
\hline$\beta, \beta$-carotene & 193 & $>200$ & - & - & - & $>200$ & $>200$ & $>200$ & $>200$ & $><1.0$ \\
\hline Gallic acid & 19 & 29 & - & - & - & 24 & 81 & 75 & 49 & 2.48 \\
\hline$A_{540}$ & 1.3 & 0.6 & 0.81 & 0.34 & 0.49 & & 0.56 & 0.5 & 0.51 & \\
\hline
\end{tabular}

Near confluent cells were incubated for 24 hours without or with various concentrations of each compound, and the relative viable cell number (absorbance at $540 \mathrm{~nm}$ of the MTT-stained cell lysate) was determined by the MTT method. The viable cell number of HL-60 cells was determined by trypan blue exclusion. The $\mathrm{CC}_{50}$ was determined from the dose-response curve. Each value represents the mean from duplicate determinations. adetermined by the equation: $\mathrm{SI}=\left[\mathrm{CC}_{50}(\mathrm{HGF})+\mathrm{CC}_{50}(\mathrm{HPC})+\mathrm{CC}_{50}(\mathrm{HPLF}) / \mathrm{CC}_{50}(\mathrm{HSC}-2)+\mathrm{CC}_{50}(\mathrm{HSC}-3)+\mathrm{CC}_{50}(\mathrm{HSC}-4)+\mathrm{CC}_{50}(\mathrm{HepG})+\mathrm{CC}_{50}\left(\mathrm{~T}_{9} 98 \mathrm{G}\right)+\right.$ $\left.\mathrm{CC}_{50}(\mathrm{HL}-60)\right] \times 6 / 3$.

of auroxanthin (13.0\%); antheraxanthin: $2.3 \%)$; lutein + zeaxanthin $(53.7 \%)$; (Z)-isomers of lutein and zeaxanthin $(7.3 \%)$; and rubixanthin $+\beta$-cryptoxanthin $(2.8 \%)$. In the PM12 fraction lycopene $(27.5 \%)$ and $\beta, \beta$-carotene $(40.4 \%)$ were identified as the main components.

\section{Anti-H. pylori activity}

Helicobacter pylori is an important human pathogen that infects up to $50 \%$ of the human population. As the leading cause of peptic ulcers, gastritis and gastric cancer worldwide, the organism has been the subject of intensive research to unravel the mysteries of its genetics and cellular biology. Antibacterial agents from a diet rich in fruit and vegetable may be superior as $H$. pylori control agents, when compared to many non-natural products
(Kawase \& Motohashi, 2004). Carotenoids, as free radicals, play an important role in the pathogenesis of gastroduodenal mucosal inflammation, peptic ulcer disease, various micronutrients are considered to protect the gastric mucosa by scavenging the free radicals. Among the tested PM2 and PM9-12 extracts only the PM10 and 11 displayed some anti- $H$. pylori effects $\left(\mathrm{MIC}_{50}=8.2 \mu \mathrm{g} / \mathrm{ml}\right.$ and $11 \mu \mathrm{g} / \mathrm{ml}$ ) comparable to metronidazole $\left(\mathrm{MIC}_{50}=\right.$ $7.0 \mu \mathrm{g} / \mathrm{ml}$ ) (Table 1). The other compounds PM2, 9 and 12 had moderate activity.

\section{Cytotoxic activity}

Carotenoids showed potent in vitro anti-tumor promoting activity (Garewal, 1993). A higher intake of carotenoids-rich foods is associated with a reduced risk of

Table 3. Effect of Rose hips carotenoids on the multidrug resistance of L-5178 cells

\begin{tabular}{|c|c|c|c|c|c|}
\hline Extract & Concentration $(\mu \mathrm{g} / \mathrm{ml})$ & FSCa & $\mathrm{SSC}^{\mathrm{a}}$ & FL-1 ${ }^{a}$ & Fluorescence activity ratio \\
\hline Par (control)b & - & 546.05 & 224.80 & 936.73 & \\
\hline$M D R+R 123$ (mean)c & - & 604.47 & 303.43 & 11.81 & - \\
\hline (d)-Verapamil & 10 & 581.09 & 296.13 & 86.27 & 7.30 \\
\hline DMSO & 20 & 573.37 & 306.12 & 14.65 & 1.24 \\
\hline \multirow[t]{2}{*}{ PM9 } & 4 & 602.90 & 310.22 & 27.78 & 2.35 \\
\hline & 40 & 585.17 & 303.20 & 167.97 & 14.22 \\
\hline \multirow[t]{2}{*}{ PM10 } & 4 & 610.71 & 309.18 & 25.62 & 2.17 \\
\hline & 40 & 576.39 & 303.77 & 134.76 & 11.41 \\
\hline \multirow[t]{2}{*}{ PM12 } & 4 & 634.75 & 332.75 & 16.18 & 1.86 \\
\hline & 40 & 591.85 & 328.64 & 122.92 & 14.15 \\
\hline \multirow[t]{2}{*}{$\beta, \beta$-carotene } & 4 & 483.20 & 200.85 & 396.50 & 46.32 \\
\hline & 40 & 493.89 & 197.99 & 1612.27 & 188.34 \\
\hline
\end{tabular}

aFSC: Forward scatter count; SSC: Side scatter count; FL-1: Fluorescence intensity; bPar: a parenteral cell without MDR gene; cMDR: a parenteral cell transfected with MDR gene. 
Table 4. Radical scavenging activity of Rose hips carotenoids

\begin{tabular}{lllll}
\hline Extract & $\begin{array}{l}\text { DPPH radical } \\
\text { intensity }\end{array}$ & \multicolumn{3}{l}{$\begin{array}{l}\text { Singlet oxygen } \\
\text { intensity }\end{array}$} \\
\hline & $\begin{array}{l}\text { concentra- } \\
\text { tion }(\mu \mathrm{g} / \mathrm{ml})\end{array}$ & $\%$ & $\begin{array}{l}\text { concentra- } \\
\text { tion }(\mu \mathrm{g} / \mathrm{ml})\end{array}$ & $\%$ \\
\hline control & 0 & $100^{\mathrm{a}}$ & 0 & $100^{\mathrm{b}}$ \\
PM9 & 1000 & 51.5 & 400 & 97.7 \\
PM10 & 1000 & 58.0 & 400 & 89.2 \\
PM12 & 1000 & 36.6 & 400 & 87.6 \\
$\beta, \beta-c a r o t e n e$ & 1000 & 6.2 & 400 & 80.2 \\
\hline
\end{tabular}

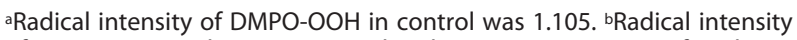
of DPPH in control was 1.977. Each value represents mean of triplicate assays. S.D. $<10 \%$.

the development of cancer formation. Capsanthin and related carotenoids isolated from the fruits of red paprika exhibited potent antitumor-promoting activity (Maoka et al., 2001). Cytotoxic activities of PM2, PM9-12 was compared to $\beta, \beta$-carotene and gallic acid against six human tumor cell cultures and three normal cell cultures (Table 2). The cytotoxic effect of PM compounds were in the same range but somewhat lower than that of gallic acid as control. The tumor-specific cytotoxicity as indicated by SI selective toxicity was only slightly observed in case of PM10 and PM11. The safety index (SI) values of PM10 and PM11 were 1.9 and 2.5, respectively (Table 2).

\section{MDR reversal on tumor cells}

MDR is a major problem in cancer treatment. The overexpression of drug transport proteins is a major mechanism for the MDR. In tumor cells overexpressing P-glycoprotein (P-gp), this results in reduced intracellular drug concentrations which in turn decrease the efficacy of a broad spectrum of some antitumor drugs. Molnár and coworkers have recently examined MDR modulating activity of several carotenoids and shown that capsanthin and capsorubin enhanced the drug accumulation most potently (Molnár et al., 2004). We measured the ability of PM9-10 and PM12 extracts to inhibit the P-gP mediated R-123 efflux in the MDR mouse T cell lymphoma L5178 transfected by human MDR1 gene, which was cultured in colchicine-containing medium. The ability of PM9, 10 and 12 was studied on the drug accumulation of MDR tumor cells. These extracts showed dose dependent reversal of $\mathrm{ABC}$ transporter. Interestingly the $\beta, \beta$-carotene was more effective the same concentrations on the MDR cells, however these concentrations were toxic for the tested cells as the SSC and FSC values shows (Table 3).

\section{Radical scavenging activity}

Carotenoids are involved in the scavenging of two of reactive oxigen species (ROS), singlet molecular oxygen and peroxy radicals generated in the process of lipid peroxidation (Sies et al., 1993). At $400 \mu \mathrm{g} / \mathrm{ml}$ concentration PM9-10 and PM12 extracts showed lower singlet oxygen scavenging activity in comparison with the control $\beta, \beta$-carotene. In DPPH assay, the electrondonating capacity was strongest in the following order: PM10>PM9 > PM12> $\beta, \beta$-carotene (Table 4).

\section{CONCLUSION}

Carotenoids are important dietary nutrients having antioxidant potential and are consequently being considered as important preventive strategic molecules. Antioxidants may protect against oxidative damages both by directly neutralizing reactive oxidants and by modulating gene expression contributing to oxidative stress (Silvaas et al., 2004). A mixture of carotenoids with different chemical structures and different antioxidants might be a promising agent for the medicinal use than individual carotenoids.

\section{Acknowledgements}

This study was supported by the grants Szeged Foundation of Cancer Research, OTKA K 76176 and OTKA K 83898 (Hungarian National Research Foundation).

\section{REFERENCES}

Britton G, Liaaen-Jensen S, Pfander H (2005) Carotenoids Today and Challenges for the Future. In Carotenoids Vol. 1 A: Isolation and Analysis, Britton G, Liaaen-Jensen S, Pfander H, eds, pp 13-26 Birkhäuser Verlag, Basel, Boston, Berlin.

Deli J, Molnár P, Ósz E, Tóth G (2000) Analysis of Carotenoids in the Fruits of Asparagus falcatus: Isolation of 5,6-Diepikarpoxanthin. Chromatographia Suppl. 51: 183-187.

Garewal HS (1993) Potential role of beta-carotene and antioxidant vitamins in the prevention of oral cancer. Ann NY Acad Sci 689: 260268.

Kawase M, Motohashi N (2003) New multidrug resistance reversal agents. Curr Drug Targets 4: 31-33.

Kawase M, Motohashi N (2004) Plant-derived leading compounds for eradication of Helicobacter pylori. Current Med Chem-Anti-Infective Agents 3: $89-100$.

Kessel D (1989) Exploring multidrug resistance using rhodamine 123. Cancer Commun 1: $145-149$.

Krinsky N, Johnson E (2005) Carotenoid actions and their relation to health and disease. Mol Aspects Med 26: 459-516.

Maoka T, Mochida K, Kozuka M et al. (2001) Cancer chemopreventive activity of carotenoids in the fruits of red paprika Capsicum annuum L. Cancer Lett 172: 103-109.

Molnár J, Mucsi I, Molnár A, Gyémánt N, Szabó M, Varga A, Molnár P, Tóth G (2004) Modulation of multidrug resistance and apoptosis of cancer cells by selected carotenoids. In vivo 18: 237-244.

Molnár J, Engi H, Hohmann J, Molnár P, Deli J, Wesolowska O, Michalak K, Wang Q (2010) Reversal of multidrug resistance by natural substances from plants. Curr. Top. Med. Chem. 10: 1757-1768.

Molnár P, Deli J, Matus Z, Tóth G (2001) A csipkebogyóban kis mennyiségben előforduló karotinoidok izolálása. J. Hung. Pharm. Soc. 45(3): 146.

Molnár P, Kawase M, Motohashi N (2005a) Isolation, crystallization and handling of carotenoids and the $(E / Z)$-isomerization of carotenoids. In Functional Polyphenols and Carotenoids with Antioxidative Action, Motohashi N, ed, pp. 111-133, Research Signpost, Kerala, India.

Molnár P, Kawase M, Satoh K, Sohara Y, Tanaka T, Tani S, Sakagami H, Nakashima H, Motohashi N, Gyémánt N, Molnár J (2005b) Biological Activity of Carotenoids of Red Paprika, Valencia Orange and Golden Delicious Apple. Phytother. Res. 19: 700-707.

Motohashi N, Wakabayashi H, Kurihara T, Takada Y, Maruyama S, Sakagami $\mathrm{H}$ et al: (2003) Cytotoxic and multidrug resistance reversal activity of a vegetable, 'Anastasia Red', a variety of sweet pepper. Phytother Res 17: 348-352.

Sakagami H, Jiang Y, Kusama K, Atsumi T, Ueha T, Toguchi M, Iwakura I, Satoh K, Ito H, Hatano T, Yoshida T (2000) Cytotoxic activity of hydrolyzable tannins against human oral tumor cell lines - a possible mechanism. Phytomedicine 7: 39-47.

Sies H, Stahl W, Sundquist AR (1993) Antioxidant functions of vitamins $\mathrm{E}$ and $\mathrm{C}$, beta-carotene and other carotenoids. Ann NY Acad Sci 669: 7-20.

Silvaas A, Sakhi AK, Andersen LF et al. (2004) Intake of antioxidants in coffee, wine and vegetable are correlated with plasma carotenoids in human. J Nutr 134: 562-567.

Weaver JL, Szabó G, Pine PS, Gottesman MM, Goldenberg S, Aszalós A (1993) The effect of ion channel blockers, immunosuppressive agents, and other drugs on the activity of the multi-drug transporter. Int J Cancer 54: 456-461. 